\title{
Community Participation, the Missing Link towards Sustainable Solid Waste Management: Lessons from Bindura Town, Zimbabwe
}

\section{Rangeti I. ${ }^{\star 1}$, Tendere T. ${ }^{1}$, Guzha E. ${ }^{1}$ and Gwisai R.D. ${ }^{2}$}

\footnotetext{
${ }^{*}$ Practical Action Southern Africa, No. 4 Ludlow Road, Newlands, P.O. Box 1744, Harare, Zimbabwe.

${ }^{2}$ Bindura University of Science Education, Department of Environmental Science, P. Bag 1020, Bindura.
}

Article No.: 050918067

Type: Research

DOI: 10.15580/GJSS.2018.2.050516085

Submitted: 04/05/2016

Accepted: 09/05/2016

Published: $14 / 06 / 2018$

${ }^{\star}$ Corresponding Author

Rangeti I.

E-mail: innoranger@gmail.com
The past decades have demonstrated the failures of top-down approaches towards waste management especially in developing countries. This has not only been attributed to technical and financial challenges, but also the low involvement of communities in service delivery. Whereas every person generates waste, they continue to be looked at as passive recipients of municipality services. Ultimately, citizens fail to recognize their role in waste management and become unwilling to either pay for service delivery or participate in clean-up campaigns. This paper reports on observation about community participation in service delivery in Bindura Town (Zimbabwe). Exploring community's innovations, attitudes and practices in solid waste management should provide lessons to policy makers on how service delivery can be enhanced by involving citizens.

\section{Keywords:}

Community participation, Bindura, 


\section{INTRODUCTION}

One of the major challenges worrying mankind in urban areas today especially in developing countries is poor solid waste management (Desa, Kadir, \& Yusooff, 2012; Guerrero, Maas, \& Hogland, 2013; Henry, Yongsheng, \& Jun, 2006). Despite the growing research of the threats associated with improper solid waste disposal to both the environment and human health, it is of concern that solid waste management has remained a mammoth task for municipalities in developing countries such as Zimbabwe. Solid waste management has become an emergent problem running concurrently with economic growth. Poor solid waste management has been positively correlated to high prevalence rate of communicable diseases such as typhoid, cholera, hepatitis A, malaria etc (Abul, 2010; Ogunrinola \& Adepegba, 2012; Sankoh, Yan, \& Tran, 2013).

The World Bank (2009) highlighted that developing countries spend 20-50 per cent of their budget on solid waste management; however 30-60 per cent of the urban solid waste remains uncollected. The poor performance of municipalities has been attributed to many factors including lack of funds, inappropriate equipment, inefficient management and unskilled personnel (UNEP 2009 (Mahadevia \& Wolfe, 2008; Pariatamby \& Tanaka, 2013; Ramachandra, 2006). Increased economic development, rapid population growth and improvement of living standards are among the factors attributed to increased quantity and complexity of waste being generated. For example, eating habits have generally been shifting towards packaged fast foods in most urban areas in developing countries (Mudzengerere \& Chigwenya, 2012). In Zimbabwe, this is evident by the increase of food pack waste in street corners as a result of the introduction of the multicurrency system (Figure 1).

Cultural diversity also tends to influence the community's attitude and perceptive towards waste generation and management. This implies that waste management techniques suitable for a given community might not be suitable for another. For example, in most developing countries, waste is not regarded as a resource (e.g. as nutritious compost manure) or recycled (e.g. into new paper and plastic) but often treated as evil leftover that needs to be eliminated. In Harare (Zimbabwe), out of 1040-1400 tonnes of waste generated daily, only 180 tonnes are collected for disposal by the Municipality (Mlanda-Zvikaramba, 2012). None of the collected waste is composted despite being characterised as organic content with a moisture content of 55-75 per cent. The uncollected waste becomes an eyesore on street corners and alleys.

It has also been noted that governments of most developing countries have often given low priority to waste management issues as they tend to concentrate on other more pressing challenges such as high infant mortality, increased HIV/AIDS related death rates and provision of basic amenities such as potable water (Mulenga, Manase, \& Fawcett, 2004). Furthermore, Tevera (1991) attributed urban solid waste disposal problems as indicative of economic policy failures at either local authorities or national governments.

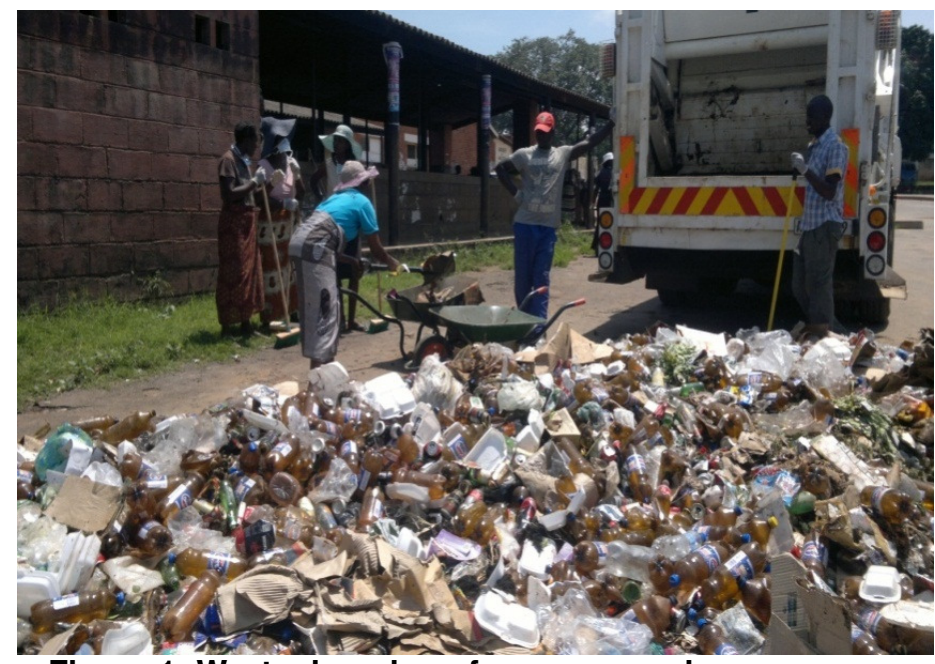

Figure 1: Waste dumping of new opaque beer bottle at Chipadze, Bindura

\section{The Bindura Situational Analysis}

Prior to the hygiene promotion project by Practical Action in 2014, the prevailing scenario in Bindura was that the municipality was solely responsible for the collection, transportation and disposal of waste. However, due to the non-consistency of waste collection schedules and lack of environmental education, residents dumped waste on street corners, open spaces and storm water drains. Most street corners were littered with heaps of garbage which have become an eyesore and health hazard (Figure 1). Bins which had been provided for use in public places by the municipality were either stolen or vandalised. Waste reception coverage in Bindura was 59 per cent (Service Level Benchmark, 2013). Residents presumed that waste thrown on the streets and open areas would be picked up by a municipality worker with the perception that they are paid to do that work.

On the other hand, the municipality had not made notable efforts to involve the community in service delivery leaving the Local Authority with a mammoth task of managing waste. While the municipality had procured two hydraulic compactor trucks to tackle the waste collection challenges, the challenge of lack of spare parts and low maintenance budgets were hampering the expected improvement of waste collection service delivery. When these sophisticated compact trucks broke down, the entire system tends to fail and suburbs would go for weeks without waste collection.

An Endline Assessment conducted by UNICEF noted that low income residents were not willing to pay for service and prioritised other basic services like food and water supply because they can easily dump waste in nearby open areas. 
During the project baseline assessment by Practical Action between January and February 2015, 65 per cent of 12 focused group discussions conducted agreed that waste was not a resource but evil leftovers which need to be eliminated. An interview with the Environmental Management Officer from EMA highlighted the need for intensive environmental education especially in high density residential areas in order to change the littering behavior and sensitise residents on waste recycling and recovery initiatives.

On the other hand, even though the process of community participation may sometimes be long and does not come cheap, experience has shown that it is almost impossible to talk about sustainable development without involving the community. However, it is of concern that literature on contribution of the community as a valuable resource in solid waste management is scarce (Fox \& Meyer, 1995; Kalwani, 2009). In Zimbabwe, very little information has been generated about community participation in solid waste management. This paper highlights the impact of community efforts in augmenting waste management service delivery in an urban area.

\section{Community Participation}

There is no fixed definition that can clearly describe the meaning of community participation. However, the term community can refer to any group of people who have something in common living within a specific geographical area where their needs are met through interdependent relationships (Fox \& Meyer, 1995).

Community participation describes any process that starts to inform, gather input or involve the community regarding decision making processes. According to Fox and Meyer (1995), community participation covers all levels of information, awareness creation, outreach, inputs involvement and collaboration. It is far more than the direct delivery of services and may contribute to strengthening both the short and long routes of accountability for service delivery.

The proponents of participatory approaches highlight the value of engagement with stakeholders in terms of greater local ownership of public actions or development projects, as well as the potential. Lack of community participation is manifested by littering habits, lack of awareness, support and public interest in waste management (Haile, 2012).

\section{Benefits of Community Participation}

Many local authorities in developing countries are constrained by lack of financial, technical and human resources and therefore are not capable or willing to deliver and maintain urban basic services(Henry et al., 2006; Pokhrel \& Viraraghavan, 2005). Studies have documented that local authorities that engage their community in service delivery tend to raise more resources and achieve better results. A report by the World Bank (1996) highlighted that community participation motivates the sense of ownership of development initiatives by members and eventually ensures the sustainability of the initiatives.

An investigation by Kalwani (2009) into factors affecting community participation in Morogoro municipal solid waste management revealed that Morogoro Municipality has not yet achieved effective community participation in solid waste due to lack of appropriate organization, mobilization and coordination of local resources; and community empowerment. It was concluded that Municipalities lacked commitment to practice community participation (Kalwani, 2009).

\section{STUDY AREA}

Bindura is the provincial capital of Mashonaland Central Province, Zimbabwe. It is located in the Mazowe Valley about $88 \mathrm{~km}$ north-east of Harare (Figure 2). The town lies in a geographical agricultural region (2b) characterised by $850 \mathrm{~mm}$ rainfall, $19.4{ }^{\circ} \mathrm{C}$ temperature and has an area of $28,347 \mathrm{~km}^{2}$. The town is situated at $17.3^{\circ} \mathrm{S}, 31.33^{\circ} \mathrm{E}$ at $1118 \mathrm{~m}$ above sea level. Administratively, Bindura Town is organised into 12 wards. The population of Bindura according to ZIMSTAT as at 2012 was 44033 , but is now estimated at 60,000 . The town extracts its raw water from Mazowe a perennial river which runs around Bindura and when Mazowe River levels are low, water from Mwenje Dam is realised. 


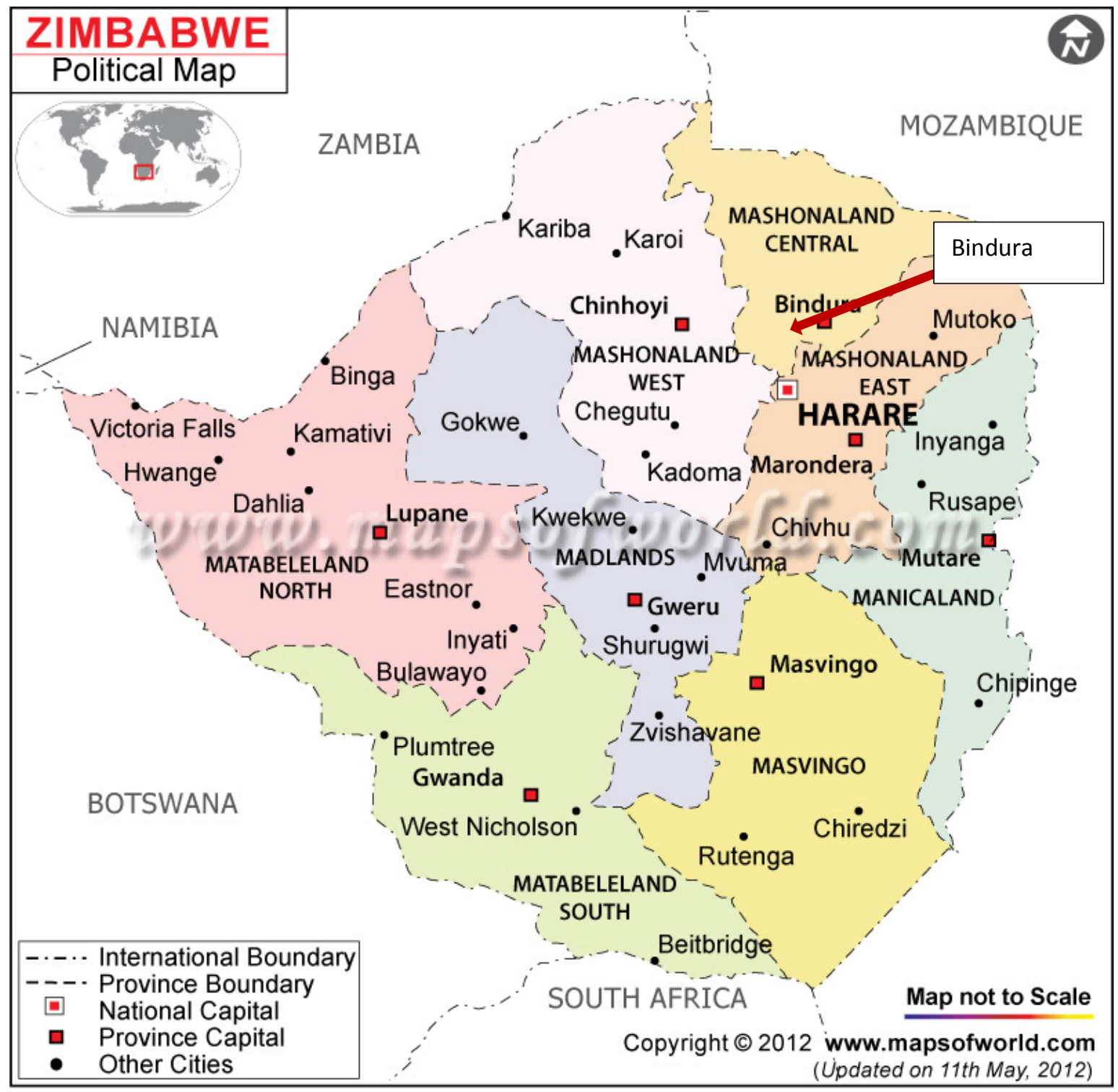

Figure 2: Location of Bindura Town

\section{MATERIALS AND METHODS}

This case-study took place from January to September 2015 in Bindura. Both qualitative and quantitative research approaches allowed the researcher to get data on the activities undertaken by the residents, community health clubs and waste management groups. 300 questionnaires were administered to households in the 12 wards of Bindura. The proportion of questionnaires for each ward was determined by the number of households in that ward. Furthermore, a total of 12 Focused Group Discussions were conducted in the 12 wards in Bindura and eight key informants were interviewed.

In order to observe the phenomenon in its natural setting, the researcher resided in the study area (Chiwaridzo- high density) between January to March 2015 and in the low density from April to September 2015. The approach allowed the researcher to find firsthand information on community participation in solid waste management by observational method. Denscombe (2004) postulates that participant observation research method tends to shed more light on people's attitudes in that it does not rely on what participants claim to do or what they think. It gathers first hand evidence of people's attitudes and practices rather than depending on secondary sources. Photos were also taken to unearth activities undertaken by the community in solid waste management during the period of January - September, 2015.

Secondary data was obtained from stakeholders documents. Existing literature from the municipality such as reports and Service Level Benchmarks (SLB) and that from key stakeholders such as Environmental Management Agency (EMA) were imperative in giving the researcher critical information on the best solid waste management initiatives being used. In addition, journals, published books, newspapers and institutional presses also gave a detailed account on issues of solid waste management 
practices in Bindura and Zimbabwe with a focus on community involvement.

The quantitative data was processed and analysed using Microsoft Excel to produce descriptive statistics while the qualitative data was transcribed and presented in light of the theoretical framework.

\section{RESULTS AND DISCUSSIONS}

\section{Methods of Community Participation in Waste Management}

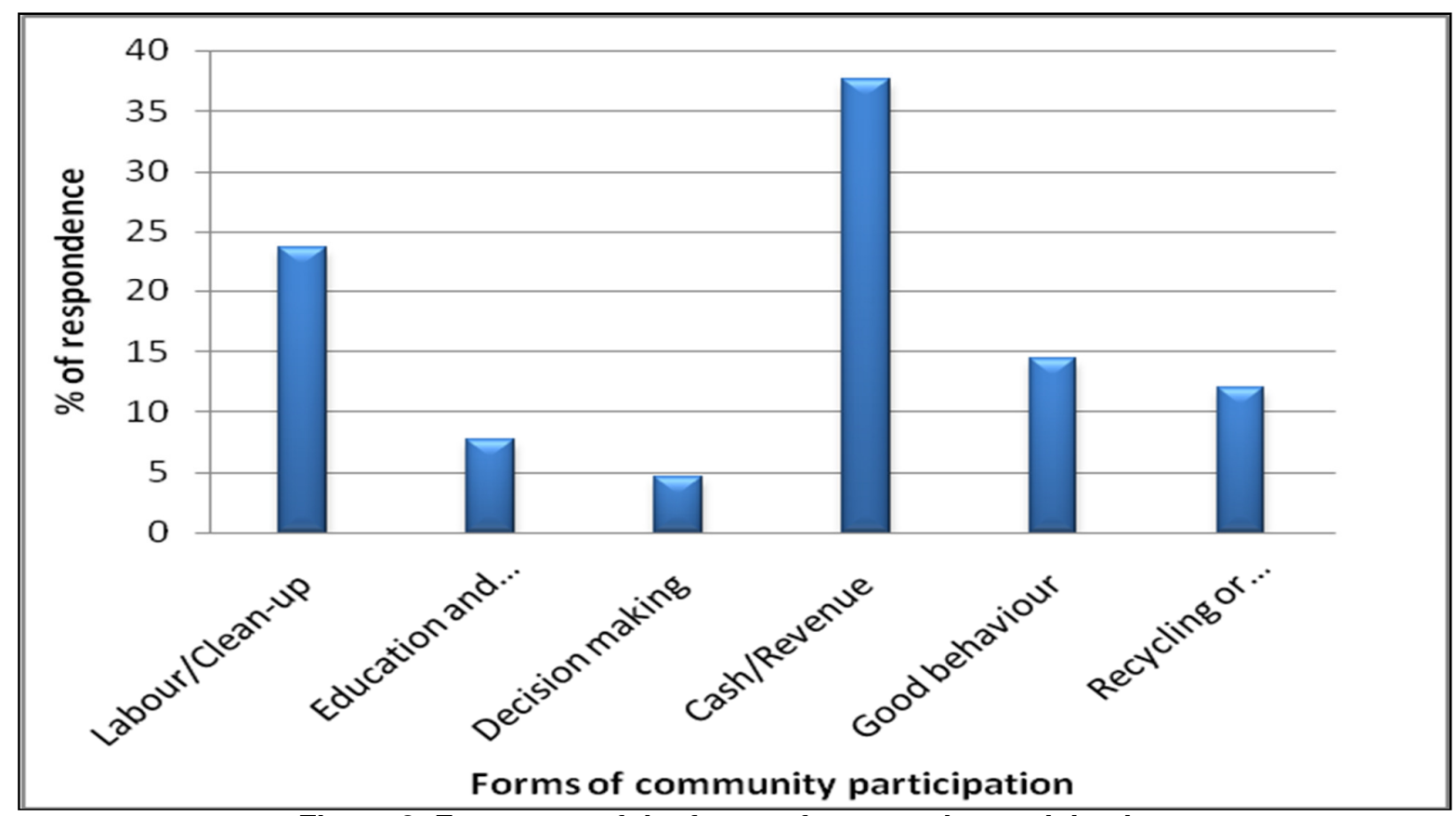

Figure 3: Frequency of the forms of community participation

Source; Author's Findings, 2015

The highest proportion (38\%) of the respondents who participated in waste management by paying for waste collection service, followed by clean up campaigns (24\%), good behavior (14\%), waste recycling (12\%), education (8\%) and education awareness (5\%), (Figure 3).

Key Informant Interviews and Focused Group Discussions (FGDs) highlighted the need for a collaborative effort in order to tackle solid waste management issues. Only 24 per cent of the respondents asserted that the clean-up campaign was an effective initiative in maintaining a clean and safe environment.

\section{Responsibility in Waste Management}

Only 34 per cent of the respondents were of the opinion that residents should bear the responsibility of management solid waste (Figure 4). However, 35 per cent of the respondents were of the opinion that the authority should bear the sole responsibility of waste management. 


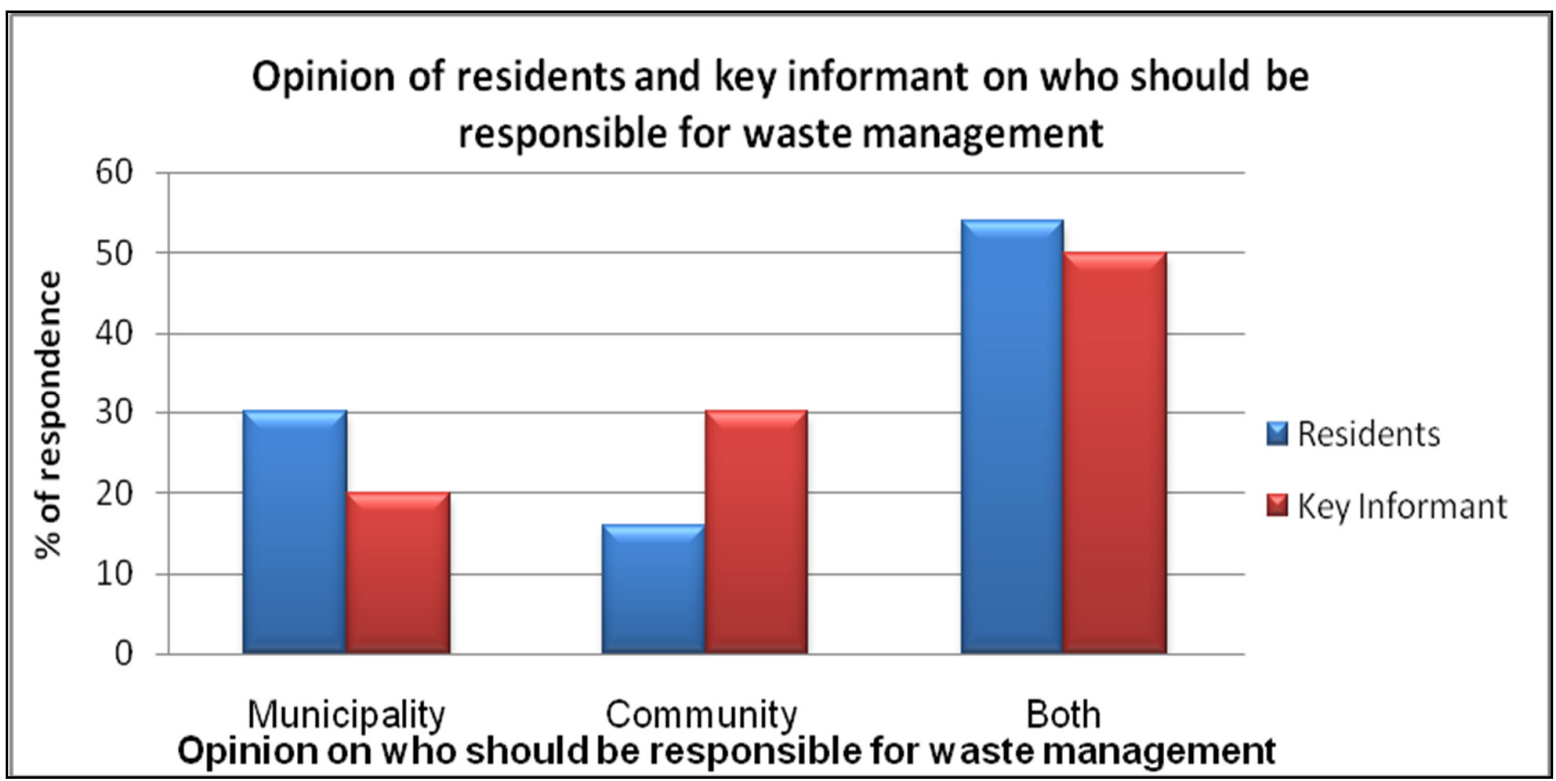

Figure 4: Source; Author's Findings, 2015

The majority (54\%) of the respondents from the community and half $(50 \%)$ of the key informants concurred on the need for partnerships in order to achieve sustainable solid waste management. Both groups agreed on the need to adopt waste separation and composting at both household and community levels as an effective strategy for improving waste management.

\section{Forms of Community Participation Observed}

\section{Good Behavior}

At household or individual level, participation in waste management may be as simple as keeping the home clean, storing waste in a proper receptacle, separate recyclable or organic materials and offering waste at the right place at the proper time for collection. During the period under study, 32 per cent of the households (11172) were reached with key messages on waste management through door to door awareness, while 578 sessions were conducted by 24 health clubs to raise awareness on good waste management at both household and community level. A total of 1894 (4.5\% of the population) people were reached through the health club approach.

The impact of such education and awareness was evident by the participation of residents during the scheduled refuse collection. It was observed that residents would make efforts to place their refuse bin at the road for collection on the scheduled date (Figure 5). In some cases, residents would actually assist municipality workers to load their bins into the refuse truck. However, 32 per cent indicated that they also felt demotivated when their bins were not collected as scheduled.

\section{Education and Awareness}

While education is not a total solution to waste management challenges, it can be agreed that it is an effective tool to bring behavioral change especially on cultural beliefs that negatively impede improved waste management practices at household and community levels. Such awareness enables the community to understand their challenge, cause and effect, and thus able to determine their role in the participation to manage solid waste. 


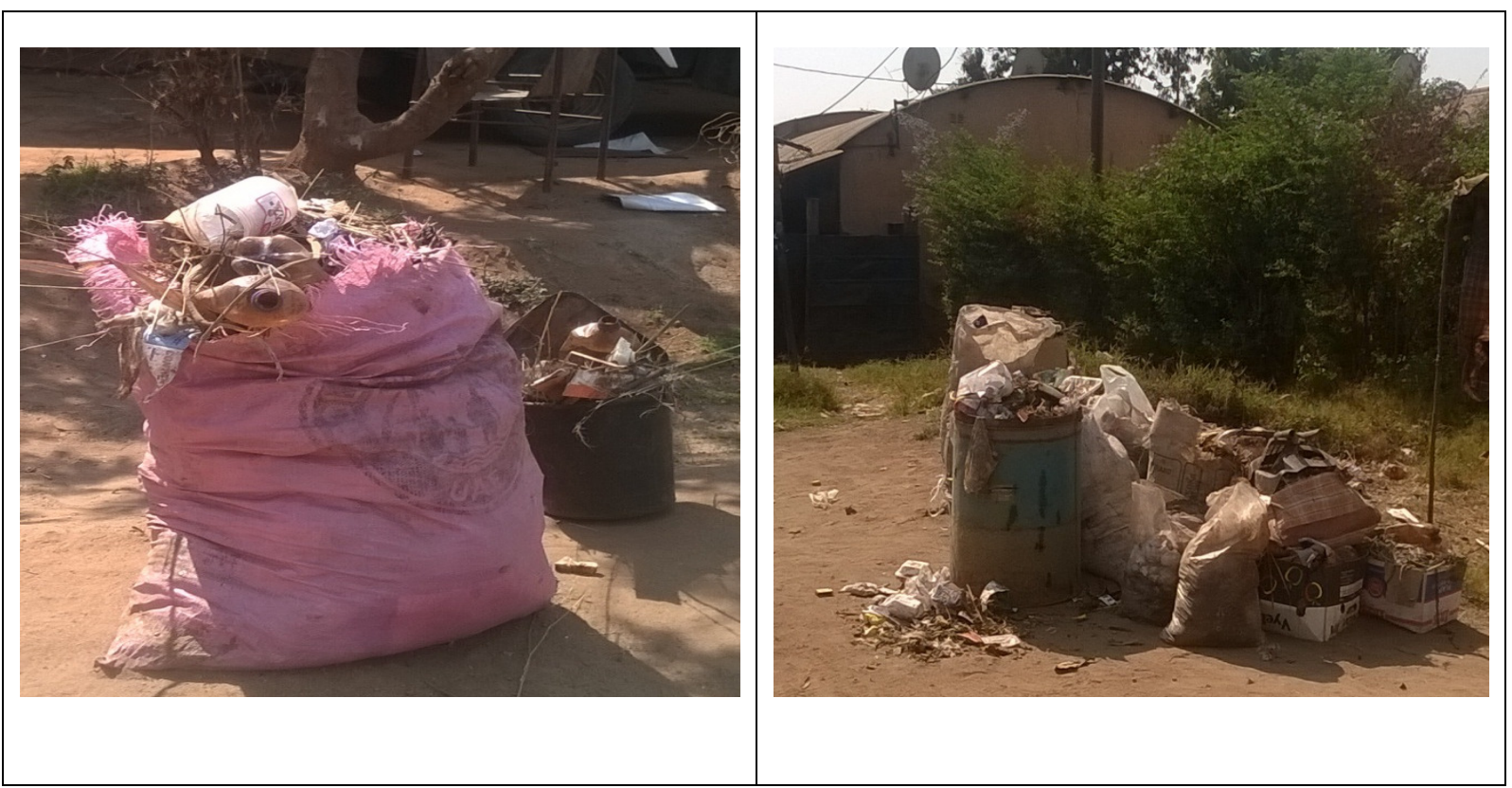

Figure 5: Bins placed on the road for collection in Ward 11 Chipadze Source; Author's Findings, 2015

The hygiene promotion project by Practical Action in Bindura focused on educating residents on the need to be responsible to their environment with special focus on waste reduction, recovery and recycle. Through the Citizen Supporting Service Delivery approach, the intervention also educated the residents to participate in service delivery through various methods. Awareness on waste management was raised through various methods including health club sessions, road shows
(Figure 6b) and clean-up campaigns (Figure 6a). Practical Action facilitated the establishment of 24 community health clubs, 6 school health clubs and 6 market health clubs which served as structures for cascading health and waste management information in both community and at schools. During the period under review, 83 educative sessions were conducted on waste separation, recycling and reuse.

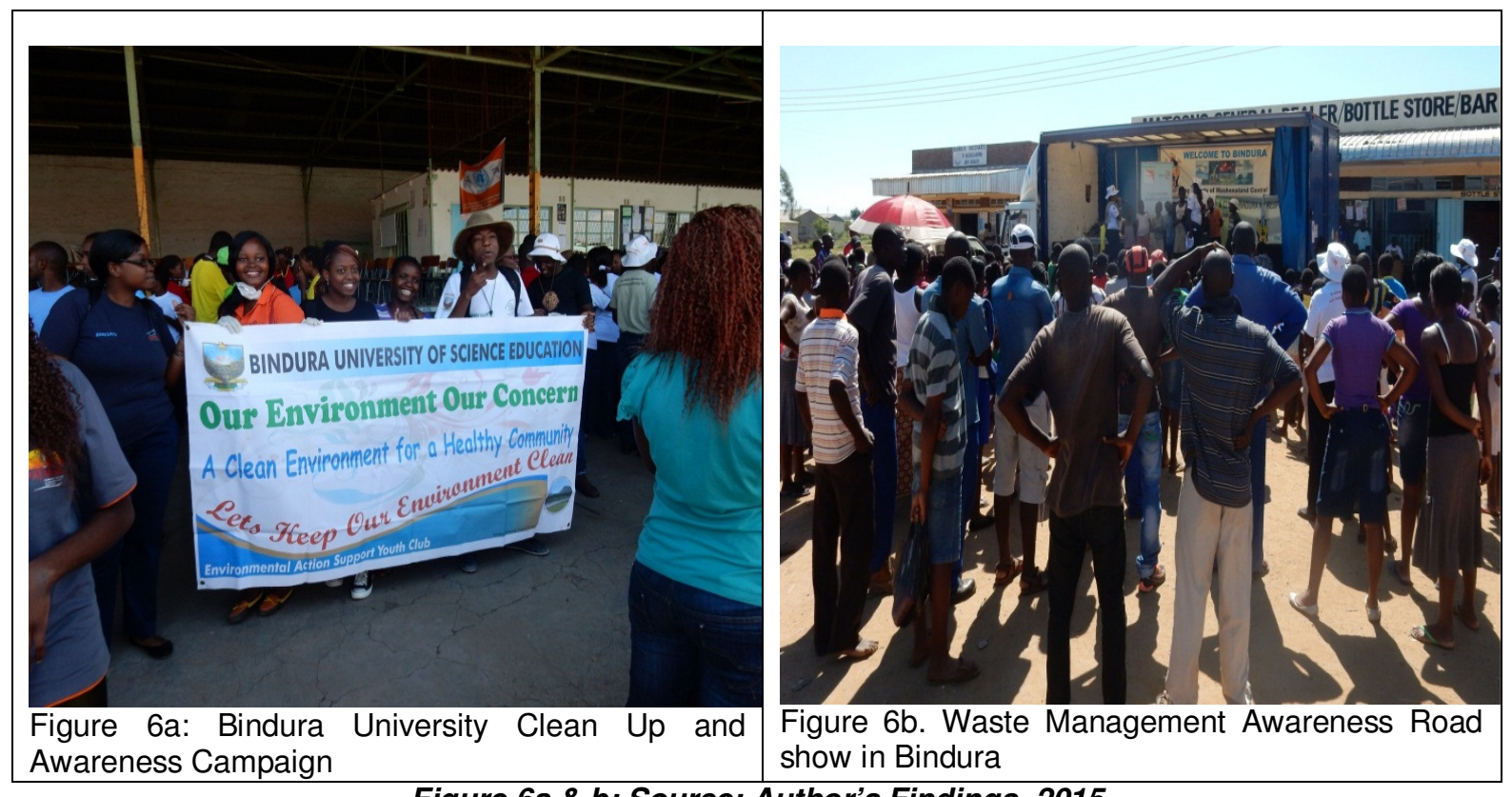

Figure 6a \& b: Source; Author's Findings, 2015 
As a result of such educative efforts, 22 per cent of the questionnaire respondents administered in September acknowledged that they had heard about solid waste management education from health club members and during clean-up campaigns. The majority (54\%) of the questionnaire respondents also now acknowledged the importance of community participating in waste service delivery.

\section{Waste Recovery and Recycling by Community Based Organization}

By reducing the total amount of solid waste collected for the landfilling (or left lying to rot in the streets), recycling and composting are land-saving and pollution-reducing strategies (Allen et al., 2002; Baud, Post, \& Furedy, 2006; Bere). As a result of the intervention, waste recycling and recovery has improved at both household and community level. At community level, success was observed through the establishment of community based waste management groups. Out of 54 community members trained on waste management, 35 per cent had already established community based waste management groups by September 2015. The six community based groups are making (1) bin, cap and jacket from cans (Figure 6b), (2) floor polish from plastic, (3) card box and plastic recovery, (4) bag from snacks plastic (figure 6a) and (5) making of mat from cloth pieces.

An interview with Cheneso Waste Management group highlighted that 29tonnes of papers and 4 tonnes of plastics has been recovered and sold to the National Waste Collector between June and September 2015. Dhobhadhobha Waste Management indicated that 5500 beverage cans have been recovered for their recycling project (Figure $7 \mathrm{~b}$ ). Beverage cans are now rarely found in ward 9 and surrounding wards were Dhobhadhobha Waste Management group operates.

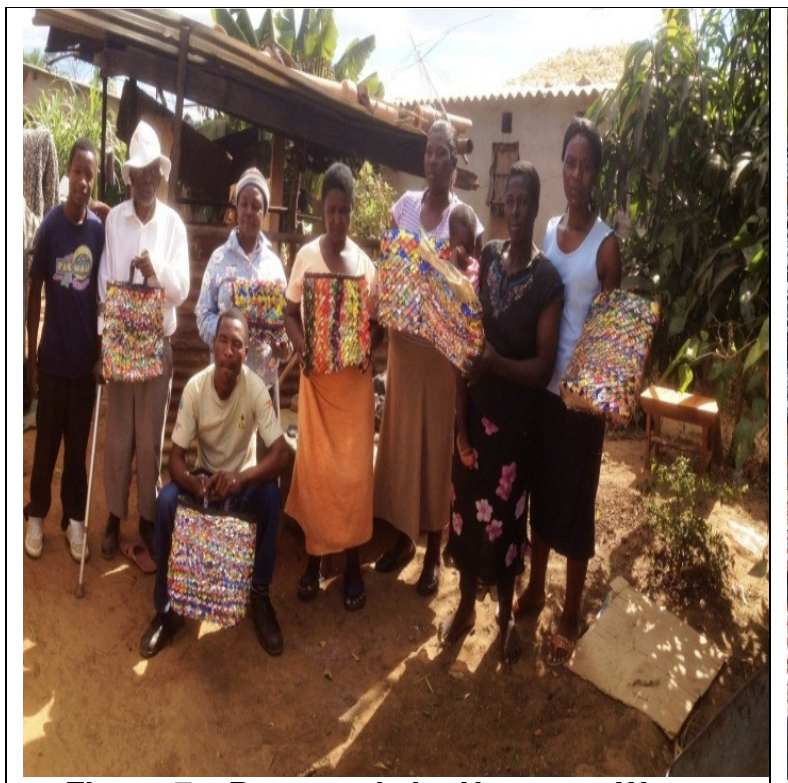

Figure 7a. Bags made by Utsanana Waste Management Group

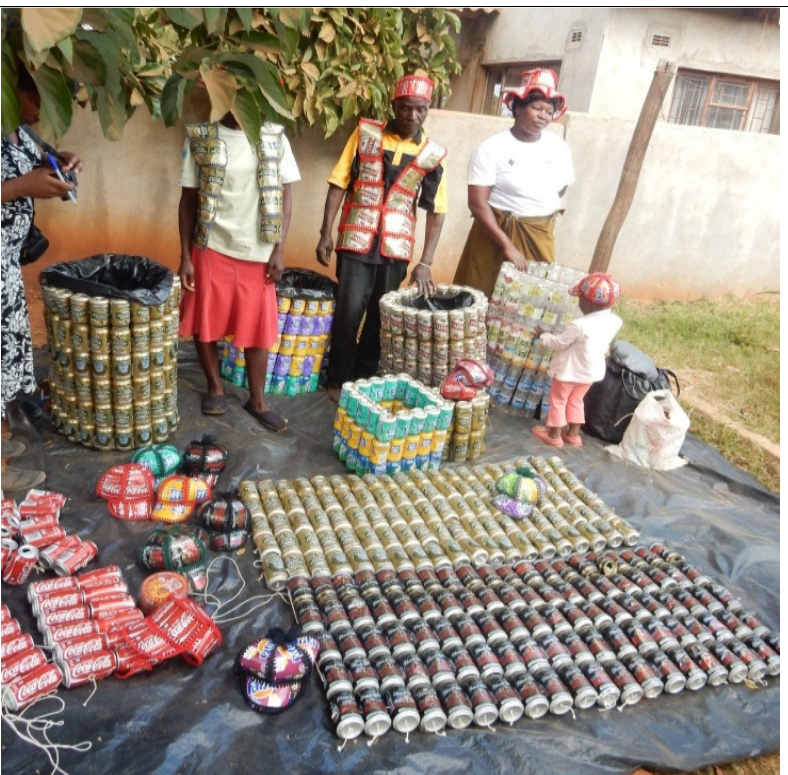

7b. Bin and hat making by Dhodhadhobha Waste Management Group

Source; Author's Findings, 2015

An interview with Bindura Municipality Environmental Health Officer highlighted that waste recovery and recycling efforts by community members has reduced operational cost by 15 per cent. By reducing solid waste headed for the landfill or dumped in streets, recycling tend to save cost associated with collection and disposal. Beside, recycling and composting saves land and reduces pollution. In consonance with this, household checklist noted that 65 per cent of the respondents were practicing composting to generate manure for their backyard gardens and agriculture. When asked where they had learnt of composting, 38 per cent of the respondents pointed school while 26 per cent cited health clubs. Some respondents highlighted that they actually copied from their neighbors after noting how compost manure was making their neighbor's backyard garden flourish.

\section{Cash and Kind}

Participation in waste management can also be through cash or kind contributions. Contributions in kind are more common with the private sector and NonGovernmental Organizations. With funds from the Australian Aid, Practical Action procured waste management equipment including wheelbarrows, hoes and shovels for use by Bindura Municipality. The availability of such materials enabled concurrent conducting of clean-ups in various wards at the same time. For example, as shown in Table 1, three clean ups were conducted concurrently in three different wards on 
the $30^{\text {th }}$ of May, while others were also conducted concurrently on the $9^{\text {th }}$ July 2015.

The local private sectors and local leaders have also been assisting the community during clean-up campaign with cash and refreshments for participants. In some cases, the local business people have provided soap for the clean-up participants.

Door to door awareness campaign by health club members led to the reach 5231 households with key messages on the importance of contribution to improved waste management by paying for service. To enhance the willingness to pay, 49 staff were trained on customer care and this led to an improvement of cost recovery.

\section{Labor}

Communities may also contribute physically through labor. Labor inputs may be voluntary or paid, for example, clearing of dumpsite or loading of garbage into a municipality vehicle. In Bindura, 27 clean-up campaigns were organised at ward, school and market levels by the various community stakeholders during the 8 months of study (Figure 8 a \&b). These were mainly organised by the health clubs, community members and their respective local leaders. The intervention also saw private sector, churches and tertiary institutions also joining in and conducting clean-up campaigns. Table 1 summarizes the community-initiated clean-up campaigns in Bindura. The Local Authority supported these efforts with wheelbarrows, hoes, picks, shovel etc. during clean up campaigns. The Environmental Management Agency (EMA) provided a roadshow truck while Practical Action and the business community supported some of the clean-ups with some refreshments. As a result, a total of 26.8 tonnes of waste were removed through clean-up activities by the community.

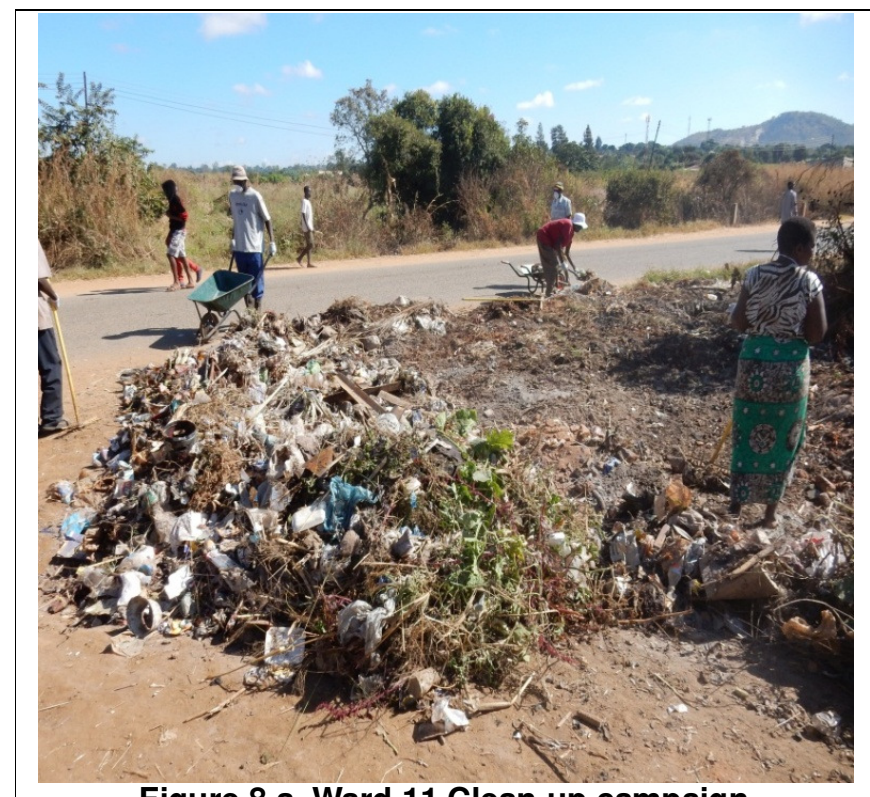

Figure 8 a. Ward 11 Clean-up campaign

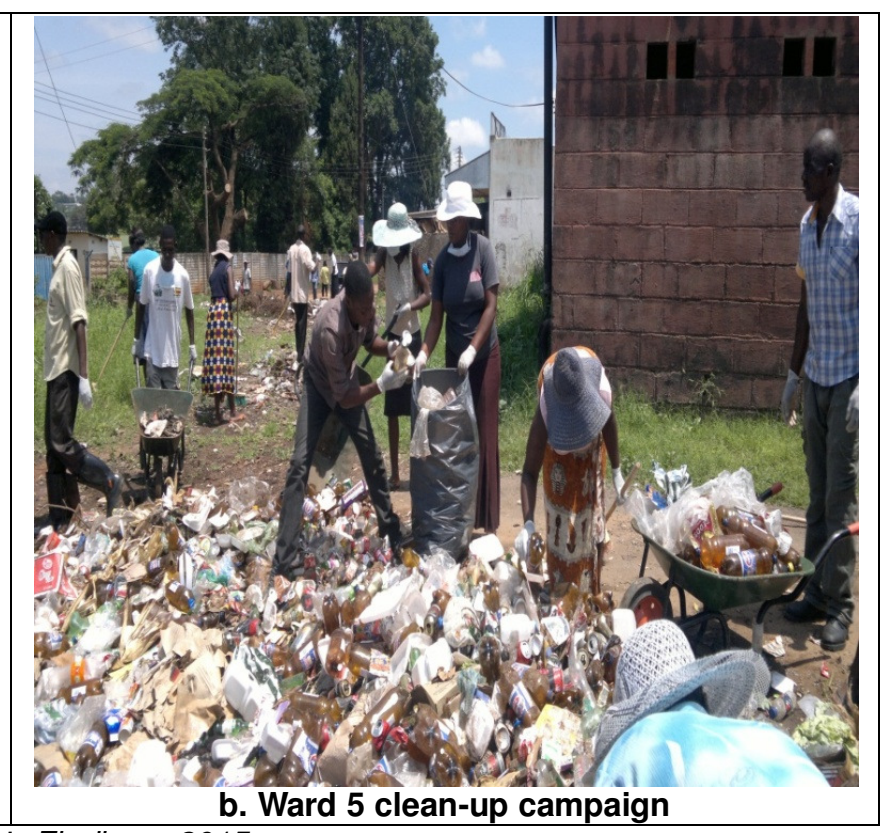

Source; Author's Findings, 2015 
Table 1: Clean-up campaigns conducted between February to September 2015

\begin{tabular}{|l|l|l|l|}
\hline Date & Ward & Total Participants & $\begin{array}{l}\text { Refuse Remove- } \\
\text { Kg }\end{array}$ \\
\hline 7-Feb & 5 & 61 & 800 \\
\hline 21-Feb & 4 & 69 & 1400 \\
\hline 21-Feb & Chipadze Pry\& Shopping centre & 60 & 1700 \\
\hline 28-Feb & 10 & 58 & 1300 \\
\hline 7-Mar & 11 & 64 & 1200 \\
\hline 14-Mar & 12 & 64 & 1600 \\
\hline 23-May & Ward 9 Clean-up & 53 & $650 \mathrm{~kg}$ \\
\hline 25-May & Ward 9 Clean-up & 20 & $500 \mathrm{~kg}$ \\
\hline 23-May & Ward 9 & 56 & $1200 \mathrm{~kg}$ \\
\hline 25-May & Ward 9 & 20 & $800 \mathrm{~kg}$ \\
\hline 28- 29 May & Ward 3 & 32 & $600 \mathrm{~kg}$ \\
\hline 29-May & Ward 10 & 32 & $750 \mathrm{~kg}$ \\
\hline 30-May & Ward 7 & 47 & $1300 \mathrm{~kg}$ \\
\hline 30-May & Ward 9 & 23 & $700 \mathrm{~kg}$ \\
\hline 30-May & Ward 12 & 76 & $1400 \mathrm{~kg}$ \\
\hline 2-Jun & Ward 6 & 27 & $650 \mathrm{~kg}$ \\
\hline 2-Jun & Ward 5 & 57 & $1300 \mathrm{~kg}$ \\
\hline 13-Jun & Ward 8 & 56 & $1400 \mathrm{~kg}$ \\
\hline 8-Jul & Ward 3 & 15 & $300 \mathrm{~kg}$ \\
\hline 9-Jul & Ward 3 & 20 & $450 \mathrm{~kg}$ \\
\hline 9-Jul & Ward 8 & 30 & $1400 \mathrm{~kg}$ \\
\hline 8-Jul & Ward 5 & 21 & $1100 \mathrm{~kg}$ \\
\hline 9-Jul & Ward 11 & 26 & $1300 \mathrm{~kg}$ \\
\hline 8-Jul & Ward 7 & 40 & 1500 \\
\hline 4 Sept & CBD (Bindura Community trust) & 21 & $500 \mathrm{Kg}$ \\
\hline 16 Sept & Bindura Bazaar & 30 & $550 \mathrm{~kg}$ \\
\hline 16 Sept & Ward 10 & 32 & $450 \mathrm{~kg}$ \\
\hline
\end{tabular}

Source; Author's Findings, 2015

In addition to the above findings, the following lessons were learnt during the case study:

1. To encourage resident's participation on issues related to waste recycling and proper waste management, community sensitization can be done in both the formal or informal education system. However, health clubs are also effective structures to cascade health information in a community.

2. For the public to be interested in solid waste management and contribute effectively there is a need for assurance that their efforts will yield success and progress. The municipality needs to enforce laws related to waste management thus safeguarding effort by the community.

3. Women are more participative during clean-up campaign and waste management awareness activities. However, factors such as religious barriers, traditions, low rate of literacy, or the burden of domestic tasks may impede their participation.

4. Local leaders also play an important role in community participation. The responsibilities of community leaders is to encourage people to subscribe for waste collection, to make sure that people pay the service charges, encourage separation of waste, and to monitor the performance of the municipality service delivery.

5. The social and economic status of the people also has a connotation on whether or, and how the people will participate in solid waste management. It is thus important to keep such factors in mind when planning for strategies to improve waste management.

\section{CONCLUSION}

The community based waste management model has so far proved to work when the local authority and other stakeholders such as private sector support community initiatives. Solid waste management requires a decentralised approach that needs active citizen participation rather than more democratic representation. Municipalities need to allow innovation and entrepreneurship from the public, providing space 
and power within a jurisdiction so that the community can work alongside health officers and engineers in improving service delivery. However, there is also need to come up with a strategy to standardise community participation. Although the approach is still in its infancy, the results achieved so far indicate great potential for the improvement of the environment by involving the community in various ways.

\section{ACKNOWLEDGMENTS}

We thank the participants for their generosity in providing information requested during the study. This work was made possible with the financial assistance of the Australian Aid. Practical Action Southern Africa and Bindura Municipality are kindly acknowledged for their contribution. The views expressed here and any errors are the authors' and do not represent any official organisation.

\section{REFERENCES}

Abul, S. (2010). Environmental and health impact of solid waste disposal at Mangwaneni dumpsite in Manzini: Swaziland. Journal of Sustainable development in Africa, 12(7), 64-78.

Allen, A., You, N., Meijer, S., Atkinson, A., University College, L. D. P. U., Development, G. B. D. f. I., \& Programme, U. N. H. S. (2002). Sustainable Urbanisation: Bridging the Green and Brown Agendas: Development Planning Unit, University College London.

Baud, I., Post, J., \& Furedy, C. (2006). Solid Waste Management and Recycling: Actors, Partnerships and Policies in Hyderabad, India and Nairobi, Kenya: Springer Netherlands.

Bere, S. Strategies for Accelerating Economic Growth: Lulu.com.

Denscombe, M. (2004). Sociology Update: Olympus Optical Company (U.K.) Limited.

Desa, A., Kadir, N. B. y. A., \& Yusooff, F. (2012). Waste Education and Awareness Strategy: Towards Solid Waste Management (SWM) Program at UKM. Procedia - Social and Behavioral Sciences, 59, 4750. http://dx.doi.org/10.1016/j.sbspro.2012.09.244

Fox, W., \& Meyer, I. H. (1995). Public Administration Dictionary: Juta \& Company.

Guerrero, L. A., Maas, G., \& Hogland, W. (2013). Solid waste management challenges for cities in developing countries. Waste Management, 33(1), 220-232.

Haile, A. (2012). Determinants of Effective Household Solid Waste Management Practices: The Case of Ambo Town-West Showa Zone. Paper presented at the Conference of Jimma University.

Henry, R. K., Yongsheng, Z., \& Jun, D. (2006). Municipal solid waste management challenges in developing countries-Kenyan case study. Waste Management, 26(1), 92-100.

Kalwani, J. (2009). Community participation in Municipal solid waste management in informal settlements: Morogoro Municipality: Tanzania.

Mahadevia, D., \& Wolfe, J. M. (2008). Solid Waste Management in Indian Cities: Status and Emerging Practices: Concept Publishing House.

Mlanda-Zvikaramba, J. C. (2012). Exploring the potential for community participation in solid waste management in Highfields Harare.

Mudzengerere, F. H., \& Chigwenya, A. (2012). Waste Management in Bulawayo city council in Zimbabwe: in search of Sustainable waste Management in the city. JSDA, 14(1), 228-244.

Mulenga, M., Manase, G., \& Fawcett, B. (2004). Building links: for improved sanitation in poor urban settlements; recommendations from research in Southern Africa: Institute of Irrigation and Development Studies.

Ogunrinola, I. O., \& Adepegba, E. O. (2012). Health and Economic Implications of Waste Dumpsites in Cities:: The Case of Lagos, Nigeria. International Journal of Economics and Finance, 4(4), 239.

Pariatamby, A., \& Tanaka, M. (2013). Municipal Solid Waste Management in Asia and the Pacific Islands: Challenges and Strategic Solutions: Springer Singapore.

Pokhrel, D., \& Viraraghavan, T. (2005). Municipal solid waste management in Nepal: practices and challenges. Waste Management, 25(5), 555-562.

Ramachandra, T. V. (2006). Management of Municipal Solid Waste: Teri Press.

Sankoh, F. P., Yan, X., \& Tran, Q. (2013). Environmental and Health Impact of Solid Waste Disposal in Developing Cities: A Case Study of Granville Brook Dumpsite, Freetown, Sierra Leone. Journal of Environmental Protection, 2013.

United Nations Environment Programme, (2009). Developing Integrated Solid Waste Management Plan Training Manual, Volume 4.

Tevera, D. S. (1991). Solid Waste Management in Harare and its Effect on the Environment: Some Preliminary Observation, Department of Geography, University of Zimbabwe, Harare. 